\title{
PENGARUH MODEL PEMBELAJARAN MAKE A MATCH TERHADAP KEMAMPUAN BERHITUNG PERMULAAN PADA ANAK KELOMPOK A
}

\author{
Ketut Pudjawan', Putu Rahayu Ujianti ${ }^{2}$, Ni Ketut Resmini ${ }^{3}$ \\ 1,2,3 Jurusan Pendidikan Guru Sekolah Dasar \\ Universitas Pendidikan Ganesha \\ Singaraja, Indonesia \\ e-mail: ketut.pudjawan@undiksha.ac.id', puturahayuujianti@undiksha.ac.id², \\ ketutresmini4@gmail.com ${ }^{3}$
}

\begin{abstract}
Abstrak
Penelitian ini bertujuan untuk mengetahui pengaruh yang signifikan kemampuan berhitung permulaan anak yang dibelajarkan model pembelajaran make a match pada anak kelompok A di Taman Kanak-kanak. Jenis penelitian ini adalah penelitian (Quasi Eksperiment) dengan rancangan post-tes only control group design. Populasi dalam penelitian ini seluruh anak kelompok $A$ yang berjumlah 171 . Teknik pengambilan sampel menggunakan teknik Sample random sampling. Berdasarkan dari teknik tersebut diperoleh sampel penelitian dengan jumlah anak 20 orang sebagai kelas eksperimen di TK Negeri Kampung Baru dan anak kelas kontrol dengan jumlah 15 orang di TK Widya Kumarasthana. Metode yang digunakan adalah observasi dan instrumen yang digunakan yaitu lembar observasi berupa checklist. Data yang dikumpulkan dianalisis menggunakan analisis statistik deskriptif, analisis statistik inferensial dan uji-t diperoleh t_hitung $=3,73$ dan t_tabel $=2,03$ pada taraf signifikansi $5 \%$ dan $\mathrm{db}=33$, dengan membandingkan hasil t_hitung dengan $t$ tabel dapat disimpulkan bahwa t_hitung > t_tabel maka H_O ditolak dan H_1 diterima. Sehingga hasil penelitian menunjukkan bahwa terdapat pengaruh yang signifikan model pembelajaran make a match terhadap kemampuan berhitung permulaan pada anak kelompok A di Taman Kanak-kanak.
\end{abstract}

Kata-kata kunci : Berhitung Permulaan, Make A Match, Anak Usia Dini

\begin{abstract}
This study aims to determine the significant effect of the ability to calculate the beginning of the child who was taught the learning model of make a match in group A children in kindergarten. The type of this research is research (Quasi Experiment) with post-test design only control group design. The population in this study were all group A children which numbered 171. The sampling technique uses the Sample random sampling technique. Based on the technique, the research sample was obtained with the number of children 20 people as the experimental class in the Kampung Baru State Kindergarten and the control class child with a total of 15 people at Widya Kumarasthana Kindergarten. The method used is observation and the instrument used is the observation sheet in the form of a checklist. Data collected were analyzed using descriptive statistical analysis, inferential statistical analysis and t-test obtained t_count $=3.73$ and t table $=2.03$ at the significance level of $5 \%$ and $\mathrm{db}=33$, by comparing the results of $t$ _count with $t$ tabel it can be concluded that $t \_c o u n t>t$ tabel then $H_{-} 0$ is rejected and $\mathrm{H}_{-} 1$ is accepted. So that the results of the study show that there is a significant effect of the make a match learning model on the numeracy skills of the group A children in kindergarten.
\end{abstract}

Keywords: Basic Counting, Make A Match, Early Childhood 


\section{Pendahuluan}

Pendidikan anak usia dini merupakan salah satu bentuk penyelenggaraan pendidikan yang disasarkan pada pertumbuhan dan perkembangan anak. Menurut Undang-Undang No 20 Tahun 2003 (dalam Hasiana Isabella dan Aniek Wirastania 2017) tentang Sistem Pendidikan anak usia dini adalah suatu upaya yang ditujukan kepada anak sejak lahir sampai dengan usia enam tahun yang dilakukan melalui pemberian rangsangan pendidikan yang dapat membantu pertumbuhan dan perkembangan jasmani serta rohani agar anak memiliki kesiapan dalam memasuki pendidikan lebih lanjut.

Menurut Mutiah (2010:6) "anak usia dini merupakan kelompok anak yang berada dalam proses pertumbuhan dan perkembangan yang bersifat unik, artinya memiliki pola pertumbuhan dan perkembangan fisik (koordinasi motorik kasar dan halus), kecerdasan (daya pikir, daya cipta), sosio emosional, bahasa, dan komunikasi". Pendidikan anak usia dini merupakan suatu pendidikan yang akan mempersiapkan anak pada pendidikan selanjutnya, untuk itu dalam pendidikan anak usia dini tentu pendidik diharapkan dapat mengajarkan atau menumbuhkan sikap, pengetahuan, keterampilan dan daya pikir anak yang nantinya akan diperlukan untuk perkembangan dan pertumbuhan pada jenjang pendidikan yang lebih tinggi.

Menurut Permendikbud No 137 Tahun 2014 Pasal 10 ada enam aspek perkembangan anak usia dini yang berbunyi "lingkup perkembangan sesuai tingkat usia anak meliputi aspek nilai agama dan moral, fisik-motorik, kognitif, bahasa, sosial emosional, dan seni. Sebagaimana terdapat pada lampiran I yang merupakan bagian tidak terpisahkan dari peraturan menteri ini”. Salah satu aspek yang penting untuk dikembangkan di PAUD adalah aspek perkembangan kognitif khususnya untuk meningkatkan kemampuan berhitung permulaan. Aspek perkembangan kognitif ini sangat penting untuk dikembangkan, karena aspek ini memiliki keterkaitan dengan cara berfikir seseorang.

Menurut Susanto (2011:47) "kognitif merupakan suatu proses berpikir, yaitu kemampuan individu untuk menghubungkan, menilai, dan mempertimbangkan suatu kejadian atau peristiwa. Proses kognitif berhubungan dengan tingkat kecerdasaan (inteligensi) yang menandai seseorang dengan berbagai minat terutama sekali ditujukan kepada ide-ide dan belajar".

Menurut Susanto (2011:48) "pada dasarnya pengembangan kognitif dimaksudkan agar anak mampu melakukan eksplorasi terhadap dunia sekitar melalui panca inderanya, sehingga dengan pengetahuan yang didapatkannya tersebut anak akan dapat melangsungkan hidupnya dan menjadi manusia yang utuh sesuai dengan kodratnya sebagai makhluk Tuhan untuk mencapai kepentingan dirinya dan orang lain". Jamaris (2010:32) menyatakan bahwa "kognitif merupakan proses yang terjadi secara internal di dalam otak pada waktu manusia sedang berpikir. Kemampuan kognitif berkembang secara bertahap dan sejalan dengan perkembangan fisik dan perkembangan saraf-saraf yang berada di dalam susunan saraf pusat atau otak". Kognitif merupakan proses yang terjadi secara internal di dalam otak pada waktu manusia sedang berfikir. Depdiknas (2007:4) menjelaskan bahwa "anak usia TK adalah masa yang sangat strategis untuk mengenalkan berhitung di jalur matematika, karena usia TK sangat peka terhadap rangsangan yang diterima dari lingkungan". terhadap rangsangan yang diterima dari lingkungan".

Menurut Susanto (2011:98) kemampuan berhitung permulaan merupakan, kemampuan

yang dimiliki setiap anak untuk mengembangkan kemampuannya, karakteristik perkembangannya dimulai dari lingkungan yang terdekat dengan dirinya, perkembangan kemampuan anak dapat meningkat ketahap pengertian mengenai jumlah yaitu berhubungan dengan jumlah dan pengurangan. 
Mengingat begitu pentingnya kemampuan berhitung bagi anak, maka berhitung perlu diajarkan sejak dini pada anak, dengan berbagai media maupun model yang tepat tentunya yang dapat menarik perhatian dan semangat anak dalam mengikuti pembelajaran di kelas, sehingga otak anak akan terlatih untuk terus berkembang dan berfikir. Tujuan memberikan pembelajaran berhitung di Taman Kanak-kanak (TK) yaitu agar anak mengetahui dasar-dasar pembelajaran berhitung, sehingga pada saat anak mengikuti pembelajaran berhitung pada jenjang selanjutnya yang lebih kompleks anak akan mudah untuk memahami dan mengerti, karena sudah mengetahui dasar dari pembelajaran berhitung.

Berhitung sangat diperlukan dalam kehidupan sehari-hari. Oleh sebab itu guru sebagai sumber belajar bagi anak diharapkan mampu memberikan kegiatan ataupun menentukan model pembelajaran yang sesuai dengan karakteristik anak usia 5 sampai 6 tahun, karena anak usia 5 tahun belum mampu melakukan kegiatan berhitung dengan sesungguhnya (berhitung dengan bilangan abstrak). Masa ini anak masih berada pada tahap berhitung permulaan yaitu anak berhitung dengan menggunakan benda-benda lingkungan yang terdekat dengan dirinya dengan suasana permainan yang menyenangkan. Pembelajaran di taman kanak-kanak seharusnya dalam suasana yang menyenangkan dan bersifat permainan bagi anak, dalam pelaksanan pembelajaran guru menggunakan bahasa dan penjelasan yang mudah untuk dipahami dan dimengerti oleh anak dengan menggunakan model pembelajaran yang bervariasi atau menggunakan media kongkret yang bersifat nyata sehingga mepermudah anak memahami materi yang disampaikan, dan pada akhirnya akan dapat meningkatkan pengetahuan anak khususnya dalam bidang berhitung permulaan.

Berdasarkan hasil observasi yang dilakukan di lapangan, diperoleh informasi bahwa kemampuan berhitung permulaan anak kelompok $A$ sudah distimulasi oleh guru namun sebagian besar anak-anak menganggap pembelajaran matematika sulit untuk dipahami dan dimengerti. Hal ini dikarenakan masih adanya anak yang belum mampu memecahkan masalah dalam hal memahami konsep berhitung bila tidak diberikan contoh benda nyata, anak juga belum mampu mengetahui konsep banyak dan sedikit, membilang banyak benda 1-10, dan mengurutkan angka 1-20 atau berhitung 1-20.

Selain itu sistem pembelajaran yang digunakan masih didominasikan dengan pembelajaran yang menitikberatkan pada pembelajaran konvensional yaitu dengan memberikan ceramah dan bercerita, sehingga pembelajaran menjadi kurang menarik dan menyenangkan bagi anak, menerapkan pembelajaran yang bersifat seperti itu justru akan membuat anak menjadi kurang bersemangat dan bahkan membuat anak menjadi cepat bosan dalam pembelajaran.

Melihat hal tersebut peneliti menawarkan solusi yaitu dengan cara menerapkan model pembelajaran yang tepat dan sesuai dengan karakteristik anak usia 4 sampai 5 tahun untuk menstimulasi kemampuan berhitung permulaan pada anak kelompok A. Peneliti meyakini model pembelajaran make a match akan memberikan peningkatan yang baik terhadap pembelajaran berhitung permulaan pada anak. Menggunakan model pembelajaran make a match dapat membangun pengetahuan anak mengenai berhitung permulaan karena dalam kegiatan belajar yang akan diberikan anak bisa membayangkan dan melihat langsung apa yang sedang dijelaskan oleh guru.

Model pembelajaran make a match adalah cara mengajar dengan mencari pasangan melalui kartu pertanyaan dan jawaban yang harus ditemukan oleh anak, salah satu keunggulannya adalah anak mencari pasangan sambil belajar suatu konsep atau topik dalam suasana yang menyenangkan. Penggunaan model pembelajaran make a match, diharapkan dapat meningkatkan kemampuan anak dalam berhitung permulaan. 
Suyatno (dalam Mariani, 2017) menyatakan bahwa, model make a match adalah model pembelajaran dimana guru menyiapkan kartu yang berisi soal atau permasalahan dan menyiapkan kartu jawaban kemudian siswa mencari pasangan kartunya. Model pembelajaran make a match merupakan bagian dari pembelajaran kooperatif. Model make a match melatih siswa untuk memiliki sikap sosial yang baik dan melatih kecepatan berfikir siswa.

Menurut Saputri (2016:3) "tipe mencari pasangan (make a match) dapat menciptakan pembelajaran yang menyenangkan, menumbuhkan keaktifan siswa, dan menumbuhkan rasa ingin tahu siswa sehingga siswa akan bersemangat belajar. Keunggulan menggunakan model pembelajaran kooperatif tipe make a match yaitu anak didik mencari pasangan sambil belajar mengenai suatu konsep atau topik dalam suasana yang menyenangkan. Model ini juga dapat digunakan untuk semua mata pelajaran dan untuk semua tingkatan usia anak didik, untuk anak Taman Kanak-Kanak model pembelajaran ini dapat mengajarkan anak tentang cara berkomunikasi dan matematika secara tidak langsung". Pembelajaran dengan model make a match dilakukan dengan cara menggunakan kartu yang bertuliskan simbol bintang sebagai kartu soal serta kartu yang bertulikan angka yang berupa kartu jawaban dan kartu yang berisi urutan angka misalnya: 1, 4, 6, 8, 9, dan kartu jawaban berupa kartu yang bertuliskan angka 2, $3,5,7,10$. Dengan menerapkan model pembelajaran make a match tentu anak akan merasa tertarik dan senang dalam mengikuti kegiatan pembelajaran di kelas yang diberikan oleh guru, karena dalam proses pembelajarannya anak diajak untuk bermain sambil belajar untuk memecahkan permasalahan yang sedang dihadapi untuk mencapai tujuan tertentu.

Tujuan dari penelitian yang ingin dicapai adalah untuk mengetahui pengaruh yang signifikan model pembelajaran make a match terhadap kemampuan berhitung permulaan pada anak kelompok A di Taman Kanak-kanak

Berdasarkan hal tersebut, perlu ditindak lanjut dengan melakukan sebuah penelitian yang berjudul "Pengaruh Model Pembelajaran Make A Macth Terhadap Kemampuan Berhitung Permulaan Pada Anak Kelompok A.

\section{Metode}

Penelitian ini dilaksanakan di Gugus II Kecamatan Buleleng yaitu di TK Negeri Kampung Baru dan TK Widya Kumarasthana. Waktu pelaksanaan penelitian ini akan disesuaikan dengan kalender pendidikan di Taman Kanak-Kanak Gugus II Kecamatan Buleleng tahun pelajaran 2018/2019 dengan pertemuan 12 kali dimasing-masing TK.

Penelitian yang digunakan yaitu penelitian eksperimen, Sugiyono (2010:72) berpendapat bahwa penelitian eksperimen dipergunakan untuk mencari pengaruh dari perlakuan tertentu terhadap kondisi terkendali, eksperimen merupakan penelitian yang dimaksudkan untuk mengetahui ada tidaknya akibat dari treatment pada subjek yang diselidiki. Sehingga pada dasarnya penelitian ini bertujuan untuk mengetahui pengaruh model pembelajaran make a match terhadap kemampuan berhitung permulaan pada anak di Taman Kanak-kanak.

Penelitian ini bermaksud untuk mencari pengaruh dari perlakuan tertentu terhadap kondisi terkendali. Penielitian ini tergolong ke dalam penelitian eksperimen semu (Quasi Eksperimental), dengan rancangan penelitian post-tes only control group design. Dalam penelitian ini dimulai dengan menentukan kelompok yang akan dijadikan kelompok eksperimen yang diberi perlakuan berupa penerapan model pembelajaran make a match, sedangkan pada kelompok kontrol tidak diberikan perlakuan melainkan tetap membelajarkan anak dengan model konvensional. 
Sugiyono (2015: 61) menjelaskan bahwa "Populasi adalah wilayah generalisasi yang terdiri atas objek atau subjek yang mempunyai kualitas dan karakteristik tertentu yang ditetapkan oleh peneliti untuk dipelajari kemudian ditarik kesimpulannya". Populasi yang dimaksud dalam penelitian ini adalah seluruh anak kelompok A di Taman Kanak-Kanak Gugus II Kecamatan Buleleng. Sehingga terdapat sembilan populasi di Taman Kanak-anak yang menjadi populasi dalam penelitian ini. Populasi yang ada kemudian diuji kesetaraannya dengan menggunakan uji ANAVA A satu jalur (Koyan, 2012:42). Uji analisis data dari setiap kelompok diambil dari skor kemampuan kognitif yang diperoleh dari kemampuan berhitung permulaan. Skor-skor tersebut kemudian dianalisis varian dengan hipotesis sebagai berikut.

Hipotesis:

$\mathrm{H}_{0}=$ Kelompok dalam populasi setara

$\mathrm{H}_{1}=$ Kelompok dalam populasi tidak setara

Jika $\mathrm{F}_{\text {hitung }}>\mathrm{F}_{\text {tabel }} \mathrm{H}_{0}$ ditolak $\mathrm{H}_{1}$ diterima sehingga kelompok tidak setara. Jika Fhitung < Ftabel $\mathrm{H}_{1}$ ditolak $\mathrm{H}_{0}$ diterima sehingga kelompok setara. Berdasarkan hasil uji kesetaraan menggunakan ANAVA A satu jalur pada taraf signifikansi $5 \%$ diperoleh nilai $F_{\text {hitung }}=1,10<F_{\text {tabel }}$ $=1,93$ dengan $\mathrm{db}_{\text {antar }}=8$ dan $\mathrm{db}_{\text {dalam }}=162$. Sehingga dapat dinyatakan bahwa populasi homogen atau setara.

Agung (2016:8) menyatakan "sampel merupakan sebagian yang menjadi wakil dari populasi tersebut, artinya sampel merupakan bagian dari populasi yang secara langsung dikenai penelitian". Sudjana (dalam Agung, 2016) menyatakan sampel merupakan sebagian yang diambil dari populasi. Kemudian menurut Bungin (2005:102) "sampel adalah wakil semua unit dan sebagainya yang ada didalam populasi". Pada penelitian ini, teknik pemilihan sampel kelompok eksperimen dan kelompok kontrol, digunakan teknik sample random sampling.

Penentuan sampel ini dilakukan dengan cara diundi. Dari enam Taman Kanak-kanak yang ada di Gugus II Kecamatan Buleleng, dilakukan pengundian pada tahap pertama untuk memperoleh dua sekolah atau kelas yang akan dijadikan sampel penelitian.

Hasil pengundian, diperoleh anak kelompok A1 berjumlah 20 orang di TK Negeri Kampung Baru sebagai kelas eksperimen dan anak kelompok A jumlah anak 15 orang di TK Widya Kumarasthana sebagai kelas kontrol.

Data kemampuan berhitung permulaan dalam penelitian ini dikumpulkan dengan menggunakan rubrik lembar observasi berupa checklist dengan menggunakan kategori nilai $1,2,3$. Pengujian validitas instrumen pada penelitian ini menggunakan uji validitas isi. Menurut Martono (2016:100) "validitas isi adalah validitas yang mengukur sejauh mana alat isi pengukur tertesebut mewakili seluruh aspek yang dianggap sebagai kerangka konsep yang akan diukur. Validitas isi dapat dicapai dengan menyusun indikator konsep dan variabel yang cukup luas, sehingga ia benar-benar dapat mengukur variabel yang dioperasionalkan atau kongkret". Untuk menguji validitas isi, dapat diuji menggunakan Expert Judgement. Hasil uji coba kemudian di analisis dengan menggunakan rumus Gregory, dari analisis tersebut mendapatkan hasil 1,00 yang berarti sangat tinggi.

Teknik analisis data dikumpulkan menggunakan uji analisis statistik deskriptif, uji prasyarat statistik inferensial dan uji-t. Sebelum melakukan uji hipotesis, terlebih dahulu dilakukan uji prasyarat analisis. Hasil penelitian dianalisis secara bertahap, yaitu uji prasyarat analisis dan uji hipotesis. Uji prasyarat analisis yang dilakukan adalah uji normalitas dan uji homogenitas. Sebelum melakukan analisis data, maka data yang diperoleh diuji terlebih dahulu normalitas dan homogenitasnya. Analisis deskriptif yaitu menghitung mean terlebih dahulu kemudian menghitung median dan terakhir menghitung modus. Uji prasyarat analisis menggunakan uji normalitas dan uji homogenitas. Uji normalitas sebaran data dilakukan untuk menyajikan bahwa sampel benar-benar berasal dari populasi yang berdistribusi normal. Uji 
normalitas sebaran data untuk skor kemampuan berhitung permulaan anak digunakan analisis Chi-Kuadrat. Kriteria pengujian data berdistribusi normal jika $x^{2}$ hitung $<x^{2}$ tabel dengan taraf signifikansi $5 \%$ dan derajat kebebasan $\mathrm{dk}=(\mathrm{K}-1)$.

Uji homogenitas kedua kelompok digunakan uji Fisher $(F)$. Kriteria pengujian, jika Fhitung $>$ Ftabel maka sampel tidak homogen, dan jika Fhitung <Ftabel maka sampel homogen. Pengujian dilakukan pada taraf signifikansi $5 \%$ dengan derajat kebebasan untuk pembilang $=$ $\mathrm{n} \_1-1$ dan derajat kebebasan untuk penyebut $=\mathrm{n} \_2-2$.

Uji hipotesis alternative atau hipotesis kerja $\mathrm{H} 1$ yang berbunyi "terdapat pengaruh yang signifikan model pembelajaran make a match terhadap kemampuan berhitung permulaan pada anak kelompok A di Taman Kanak-kanak", diterima. Kriteria pengujian yaitu pada taraf signifikansi $5 \%$ dengan $\mathrm{dk}=\mathrm{n} 1+\mathrm{n} 2-2$, jika harga $\mathrm{t}_{\text {hitung }}<\mathrm{t}_{\text {tabel }}$ maka $\mathrm{H}_{0}$ diterima, dan jika harga $t_{\text {hitung }}>\mathrm{t}_{\text {tabel }}$ maka $\mathrm{H}_{0}$ ditolak.

\section{Hasil dan Pembahasan}

Data hasil post-test kemampuan berhitung permulaan anak kelompok eksperimen di TK Negeri Kampung Baru menunjukkan bahwa nilai tertinggi adalah 36 dan nilai terendah adalah 22. Data rekapitulasi perhitungan skor kemampuan berhitung permulaan anak pada kelompok eksperimen menunjukkan bahwa nilai mean adalah 29,9 median 30,5 dan modus 31,5. Sebaran data kemampuan berhitung permulaan pada kelompok eksperimen dapat dilihat pada Tabel 1.

Tabel 1. Ringkasan Hasil Statistik Kemampuan Berhitung Kelompok Eksperimen

\begin{tabular}{lc}
\hline \multicolumn{1}{c}{ Statistik Deskriptif } & Hasil Post test Kelompok Eksperimen \\
\hline Mean & 29,9 \\
Median & 30,5 \\
Modus & 31,5 \\
Standar Deviasi & 3,69 \\
Varians & 13,61 \\
\hline
\end{tabular}

Tabel 2. Konversi Skala Lima Hasil Post Test Kelompok Eksperimen

\begin{tabular}{ccc}
\hline Rumus & Rentang Skor & Klasifikasi/ Predikat \\
\hline $\mathrm{Mi}+1,5 \mathrm{SDi}-<\mathrm{Mi}+3,0 \mathrm{SDi}$ & $29,76-<35,52$ & Sangat baik \\
$\mathrm{Mi}+0,5 \mathrm{SDi}-<\mathrm{Mi}+1,5 \mathrm{SDi}$ & $25,92-<29,76$ & Baik \\
$\mathrm{Mi}-0,5 \mathrm{SDi}-<\mathrm{Mi}+0,5 \mathrm{SDi}$ & $22,08-<25,92$ & Cukup \\
$\mathrm{Mi}-1,5 \mathrm{SDi}-<\mathrm{Mi}-0,5 \mathrm{SDi}$ & $18,24-<22,08$ & Tidak baik \\
$\mathrm{Mi}-3,0 \mathrm{SDi}-<\mathrm{Mi}-1,5 \mathrm{SDi}$ & $12,48-<18,24$ & Sangat tidak baik \\
\hline
\end{tabular}

Berdasarkan analisis data yang telah dilakukan, diperoleh nilai rata-rata kemampuan berhitung permulaan dengan menerapkan model pembelajaran make a match adalah 29,9. Jika dikonversi ke dalam PAP skala lima berada pada katagori sangat baik.

Data hasil post-test kemampuan berhitung permulaan anak kelompok kontrol di TK Widya Kumarasthana menunjukkan bahwa nilai tertinggi adalah 32 dan nilai terendah adalah 21. Data rekapitulasi perhitungan skor kemampuan berhitung permulaan anak pada kelompok kontrol menunjukkan bahwa nilai mean adalah 25,5 median 24,18 dan modus 24,10. Sebaran data kemampuan berhitung permulaan pada kelompok kontrol dapat dilihat pada Tabel 3 
Tabel 3. Ringkasan Hasil Statistik Kemampuan berhitung permulaan Kelompok Kontrol

\begin{tabular}{cc}
\hline Statistik Deskriptif & Hasil Post test Kelompok Eksperimen \\
\hline Mean & 25,2 \\
Median & 24,18 \\
Modus & 24,10 \\
Standar Deviasi & 3,92 \\
Varians & 15,37 \\
\hline
\end{tabular}

Berdasarkan Tabel.3 diketahui bahwa modus lebih kecil dari median dan dan lebih kecil dari mean $(\mathrm{Mo}<\mathrm{Me}<\mathrm{M})$. sehingga kurva berbentuk juling positif. Mengetahui kualitas variable kemampuan berhitung permulaan anak kelompok kontrol. Skor rata-rata dikonversikan berdasarkan penilaian skala lima untuk kelompok kontrol dapat dilihat pada Tabel 4.

Tabel 4. Konversi Skala Lima Hasil Post Test Kelompok Kontrol

\begin{tabular}{ccc}
\hline Rumus & Rentang Skor & Klasifikasi/ Predikat \\
\hline $\mathrm{Mi}+1,5 \mathrm{SDi}-<\mathrm{Mi}+3,0 \mathrm{SDi}$ & $29,76-<35,52$ & Sangat baik \\
$\mathrm{Mi}+0,5 \mathrm{SDi}-<\mathrm{Mi}+1,5 \mathrm{SDi}$ & $25,92-<29,76$ & Baik \\
$\mathrm{Mi}-0,5 \mathrm{SDi}-<\mathrm{Mi}+0,5 \mathrm{SDi}$ & $22,08-<25,92$ & Cukup \\
$\mathrm{Mi}-1,5 \mathrm{SDi}-<\mathrm{Mi}-0,5 \mathrm{SDi}$ & $18,24-<22,08$ & Tidak baik \\
$\mathrm{Mi}-3,0 \mathrm{SDi}-<\mathrm{Mi}-1,5 \mathrm{SDi}$ & $12,48-<18,24$ & Sangat tidak baik \\
\hline
\end{tabular}

Berdasarkan analisis data yang telah dilakukan, diperoleh nilai rata-rata kemampuan berhitung permulaan dengan menerapkan model pembelajaran konvensional adalah 25,2 Jika dikonversi ke dalam PAP skala lima berada pada katagori baik.

Uji prasyarat dilakukan sebelum uji hiotesis. Uji prasyarat dalam penelitian ini meliputi uji normalitas dan homogenitas hasil kemampuan berhitung permulaan. Uji prasyarat dilakukan pada hasil post-test kelompok eksperimen dan pada kelompok kontrol. Kriteria pengujian data berdistribusi normal jika $x^{2}$ hitung $<x^{2}$ tabel dengan taraf signifikansi $5 \%$ dan derajat kebebasan $\mathrm{dk}=$ (jumlah baris -1 ).

Hasil uji normalitas diperoleh harga $x^{2}$ hitung $=3,03$ dengan taraf signifikansi $5 \%$ dan derajat kebebasan $(\mathrm{dk})=\mathrm{k}-1=6-1=5$ diperoleh $x^{2}$ tabel $=11,07$, sehingga $x^{2}$ hitung $<x^{2}$ tabel, dengan demikian diterima dengan kesimpulan bahwa data skor kemampuan berhitung permulaan pada anak kelompok eksperimen berdistribusi normal. Sedangkan pada kelompok kontrol diperoleh harga $x^{2}$ hitung $=6,54$ dengan taraf signifikansi $5 \%$ dan derajat kebebasan (dk) $=\mathrm{k}-1=6-1=5$ diperoleh $x_{\text {tabel }}^{2}=11,07$, sehingga $x^{2}$ hitung $<x_{\text {tabel, }}^{2}$, dengan demikian diterima dengan kesimpulan bahwa data skor kemampuan berhitung permulaan pada anak kelompok kontrol berdistribusi normal.

Hasil homogenitas data kemampuan berhitung permulaan anak pada kelompok eksperimen dan kelompok kontrol dengan perhitungan uji fisher (uji f) diperoleh $F_{\text {hitung }}=1,13$. Selanjutnya $F_{\text {hitung }}$ dibandingkan dengan $F_{\text {tabel }}$ pada taraf signifikansi $5 \%$. Berdasarkan $F_{\text {tabel }}$ pada taraf signifikansi $5 \%$ dengan df $1=\mathrm{k}-1=2-1=1$, dan df2 $=\mathrm{n}-\mathrm{k}=35-2=33$, didapatkan harga $F_{\text {tabel }}$ sebesar 4,41. Hasil tersebut menunjukkan Fhitung $<F_{\text {tabel, sehingga dapat }}$ dikategorikan bahwa kedua kelompok data homogen.

Berdasarkan analisis data menggunakan uji-t diperoleh nilai $t_{\text {hitung }} 3,73$ sedangkan $t_{\text {tabel }}$ dengan taraf signifikansi $5 \%$ dan dk $(20+15)-2=33$ adalah 2,03 dengan demikian $t_{\text {hitung }} 3,73$ lebih besar dari pada $\mathrm{t}_{\text {tabel }}>2,03$ maka $\mathrm{H}_{0}$ ditolak dan $\mathrm{H}_{1}$ terima. Jadi dapat ditarik kesimpulan 
bahwa terdapat Penelitian ini bertujuan untuk mengetahui pengaruh yang signifikan kemampuan berhitung permulaan pada anak kelompok A di Taman Kanak-kanak. Jenis penelitian ini adalah penelitian (Quasi Eksperiment) dengan rancangan post-tes only control group design. Populasi dalam penelitian ini seluruh anak kelompok A yang berjumlah 171 . Teknik pengambilan sampel menggunakan teknik sample random sampling. Berdasarkan dari teknik tersebut diperoleh sampel penelitian dengan jumlah anak 20 orang sebagai kelas eksperimen di TK Negeri Kampung Baru dan anak kelas kontrol dengan jumlah 15 orang di TK Widya Kumarasthana. Metode yang digunakan adalah observasi dan instrumen yang digunakan yaitu lembar observasi berupa checklist. Data yang dikumpulkan dianalisis menggunakan analisis statistik deskriptif, analisis statistik inferensial dan uji-t diperoleh t_hitung $=3,73$ dan t_tabel $=2,03$ pada taraf signifikansi $5 \%$ dan $\mathrm{db}=33$, dengan membandingkan hasil t_hitung dengan t_tabel dapat disimpulkan bahwa t_hitung $>\mathrm{t}$ tabel maka $\mathrm{H}$ _0 ditolak dan $\mathrm{H}_{-} 1$ diterima. Sehingga hasil penelitian menunjukkan bahwa terdapat pengaruh yang signifikan model pembelajaran make a match terhadap kemampuan berhitung permulaan pada anak kelompok A di Taman Kanak-kanak.

Hasil analisis data kemampuan berhitung permulaan kelompok eksperimen dan kelompok kontrol memiliki perbedaan nilai rata-rata yaitu nilai rata-rata kelompok eksperimen adalah 29,9 sedangkan nilai rata-rata kelompok kontrol adalah 25,2 sehingga dapat dikatakan nilai rata-rata kelompok eksperimen lebih besar dibandingkan dengan kelompok kontrol yaitu $29,9>25,2$. Berdasarkan hal tersebut penelitian ini menunjukkan bahwa model pembelajaran make a match berpengaruh terhadap kemampuan berhitung permulaan anak. Hal ini dikarenakan kegiatan model pembelajaran make a match dapat menstimulasi kemampuan berhitung anak dengan cara anak belajar memecahkan masalah dengan pasangannya menggunakan kartu berupa simbol dan angka untuk mencapai tujuan pembelajaran.

Uraian tersebut juga serupa dengan pendapat Saputri (2016:3) "tipe mencari pasangan (make a match) dapat menciptakan pembelajaran yang menyenangkan, menumbuhkan keaktifan siswa, dan menumbuhkan rasa ingin tahu siswa sehingga siswa akan bersemangat belajar. Keunggulan menggunakan model pembelajaran kooperatif tipe make a match yaitu anak didik mencari pasangan sambil belajar mengenai suatu konsep atau topik dalam suasana yang menyenangkan. Model ini juga dapat digunakan untuk semua mata pelajaran dan untuk semua tingkatan usia anak didik, untuk anak Taman Kanak-kanak model pembelajaran ini dapat mengajarkan anak tentang cara berkomunikasi dan matematika secara tidak langsung".

Penggunaan model pembelajaran make a match dapat memberikan pengalaman belajar anak melalui bermain, sehingga suasana kelas akan menjadi lebih aktif, menyenangkan dan anak memiliki minat untuk belajar di dalam kelas. Perbedaan cara pembelajara kedua kelompok antara anak yang dibelajarkan menggunakan model pembelajaran make a match dan kelompok anak yang dibelajarkan menggunakan model pembelajaran konvensional memberikan dampak yang berbeda terhadap kemampuan berhitung permulaan. Secara singkat pemberian perlakuan kepada kedua kelompok dilakukan sebanyak 12 kali pertemuan (pada pertemuan pertama hingga pertemuan ke sebelas anak kelompok eksperimen diberikan perlakuan dengan model pembelajaran make a match sedangkan pada pertemuan ke dua belas atau dipertemuan terakhir anak diberikan post-test) pada masing-masing kelompok.

Anak-anak dikelompok eksperimen menunjukkan antusiasnya dalam belajar berhitung awal walaupun dalam pertemuan ini masih berlangsung selama dua kali anak-anak sudah terlihat mau untuk mendengarkan penjelasan dari guru dibandingkan pada hari-hari sebelumnya anak tidak mau mengikuti kegiatan, bahkan mengerjakan kegiatan yang sudah diberikan. Pertemuan selanjutnya anak mampu berhitung serta mampu menyelesaikan urutan angka yang diberikan pada saat proses pembelajaran di kelas, hal ini dikarenakan anak sudah mengenal angka walaupun masih dalam bantuan guru. Pada pertemuan kedelapan hingga pertemuan seterusnya kemampuan berhitung permulaan anak sudah sangat terlihat, hal ini 
terlihat dari lebih aktif dan antusias anak dalam mengikuti pembelajaran yang berbasis permainan dengan berbantuan kartu gambar ketika proses pembelajaran berlangsung anak yang dulunya pasif tidak menghiraukan apa yang dikatakan guru dan tidak mengerjakan kegiatan yang diberikan pada saat pembelajaran di kelas, setelah diterapkan model pembelajaran make a match selama beberapa pertemuan sebagian besar anak mengalami peningkatan dan menjadi lebih bersemangat untuk mencari tahu kegiatan yang akan diajarkan. Bahkan anak menjadi lebih antusias maju ke depan untuk mencoba mengerjakan kegiatan yang sudah disiapkan.

Berdasarkan paparan tersebut model pembelajaran make a match dapat memberikan peningkatan berhitung permulaan anak. Ini terlihat karena anak sudah mampu menyebutkan urutan bilangan, menghubungkan atau mencocokkan gambar dengan angka, dan membandingkan benda lebih banyak dan sedikit. Hasil temuan ini sesuai dengan teori Susanto (2011:107) yang menyatakan bahwa "materi berhitung yang diberikan dapat berupa menyebutkan urutan bilangan, membilang dengan benda-benda, menghubungkan atau memasangkan lambang bilangan dengan benda-benda, membedakan dan membuat kumpulan benda yang sama jumlahnya atau yang tidak sama (lebih banyak, lebih sedikit), menyebutkan hasil penambahan dan pengurangan benda, memperkirakan urutan berikutnya setelah melihat bentuk lebih dari tiga pola yang berurutan misalnya merah, putih, biru, meniru pola dengan menggunakan benda".

Berbeda halnya dengan penerapan model pembelajaran konvensional menyebabkan anak menjadi pasif atau kurang aktif karena kegiatan bersifat monoton kurang menarik perhatian, sehingga akan mengakibatkan kebosanan dalam diri anak dan membuat anak tidak fokus dalam kegiatan pembelajaran. Selain itu anak lebih senang mengganggu temannya dan tidak mendengarkan penjelasan guru. Perbedaan model pembelajaran yang digunakan dalam pembelajaran berhitung antara kelompok eksperimen yang menggunakan model pembelajaran make a match dan kelompok kontrol menggunakan model pembelajaran konvensional akan memberikan dampak yang berbeda terhadap kemampuan berhitung anak.

Hasil penelitian ini serupa dengan penelitian yang dilakukan oleh Yuliani (2017) yang berjudul "Pengaruh Video Pembelajaran Terhadap Kemampuan Berhitung Permulaan Anak Kelompok B di Taman Kanak-kanak Gugus VI Kecamatan Buleleng Tahun Pelajaran 2016/2017". Hasil penelitian menunjukkan bahwa terdapat pengaruh yang signifikan kemampuan berhitung permlaan antara kelas eksperimen dan kelas kontrol.

Kemudian, Penelitian yang dilakukan oleh Parapat, Asmidar dan Damaiwaty Ray (2018) yang berjudul "Pengaruh Penggunaan Model Make a Match Terhadap Kemampuan Mengenal Konsep Bilangan 1-10 Anak Usia 4-5 Tahun di TK Ilmi Insani”. Hasil penelitian menunjukkan bahwa lebih memuaskan anak pada kelompok eksperimen dibandingkan anak pada kelas kontrol. Hal ini terlihat dari lebih meningkatnya kemampuan mengenal konsep bilangan 1-10 anak pada kelas eksperimen dibandingkan dengan anak kelas kontrol.

Selanjutnya penelitian yang dilakukan oleh Juniawan (2017) yang berjudul "Pengaruh Model Pembelajaran Make A Match Terhadap Hasil Belajar Ipa Siswa Kelas V SD di Gugus VIII Kecamatan Sukasada Kabupaten Buleleng Tahun Pelajaran 2016/2017". Hasil penelitian menunjukkan bahwa terdapat pengaruh yang signifikan Hasil Belajar Ipa anak kelompok eksperimen yang dibelajarkan menggunkan model pembelajaran make a match dibandingkan anak yang dibelajarkan menggunakan model pembelajaran konvensional pada kelas kontrol. 


\section{Simpulan dan Saran}

Berdasarkan pemaparan hasil penelitian dan pembahasan maka dapat disimpulkan bahwa terdapat pengaruh yang signifikan model pembelajaran make a match terhadap kemampuan berhitung permulaan pada anak kelompok A di Taman Kanak-kanak. Uraian di atas dapat diperkuat dari hasil perhitungan Mean kelompok eksperimen lebih besar dibandingkan kelompok kontrol serta dari perhitungan uji hipotesis juga diperoleh bahwa t_hitung lebih besar dibandingkan t_tabel. Hal ini dikarenakan model pembelajaran make a match dapat membuat pembelajaran menjadi menyenangkan, lebih menarik perhatian, sehingga anak menjadi aktif mengikuti pembelajaran di kelas.

Saran sebagai bahan pertimbangan di TK kedepannya yaitu : kepada guru disarankan agar mampu memahami karakteristik anak, karena masing-masing anak memiliki keunikan masing-masing. Jika guru sudah memahami karakteristik anak maka penyusunan kegiatan hendaknya disesuaikan dengan karakteristik anak sehingga tujuan pembelajaraan akan mudah untuk dicapai. Selain itu penerapan model pembelajaran hendaknya divariasikan sehingga anak akan memperoleh pengalaman baru dan akan meningkatkan semangatnya.

Saran selanjutnya diharapkan kepada peneliti lain agar mampu mengembangkan model pembelajaran make a match untuk menstimulasi kemampuan yang lain, seperti pemahaman konsep bilangan, pemahaman simbol dan geometri. Dengan begitu aspek perkembangan anak akan dapat distimulasi melalui model pembelajaran yang menyenangkan dan menarik, sehingga aspek perkembangan anak akan berkembang secara optimal.

\section{Daftar Pustaka}

Agung, Anak Agung Gede. 2016. Statistika Dasar Untuk Pendidikan. Yogyakarta : CV BUDI UTAMA.

Bungin, Burhan. 2005. Metodologi Penelitian Kuantitatif. Jakarta: Kencana Prenada Media Group.

Depdiknas. 2007. Permainan Berhitung Permulaan di Taman Kanak-kanak. Jakarta : Depdiknas.

Hasiana, Isabella dan Aniek Wirastania. (2017). "Pengaruh Musik dalam Mengembangkan Kemampuan Mengenal Bilangan Siswa Kelompok A di TK Lintang Surabaya". Vol 1 No 2.

Jamaris. 2010. Orientasi Baru Psikologi Pendidikan. Jakarta: Yayasan Penamas Murni.

Juniawan, I Nyoman. 2017. Pengaruh Model Pembelajaran Make A Match Terhadap Hasil Belajar Ipa Siswa Kelas V SD Gugus VIII Kecamatan Sukasada Kabupaten Buleleng Tahun Pelajaran 2016/2017. Singaraja: Universitas Pendidikan Ganesha.

Koyan, I. W. 2012. Statistik Pendidikan (Teknik Analisis Data Kuantitatif). Singaraja: Universitas Pendidikan Ganesha Press.

Mariani. (2017). "Penerapan Model Pembelajaran Make A Match Untuk Meningkatkan Hasil Belajar Matematika Tentang Pembagian Pada Siswa Kelas li Sd Muhammadiyah 4 Batu". Volume, 3 Nomor 2. 
Martono, Nanang. 2016. Metode Penelitian Kuantitatif. Jakarta: PT Rajagrafindo Persada.

Mutiah, Diana. 2010. Psikologi Bermain Anak Usia Dini. Jakarta: Fajar Interpratama Offset.

Parapat, Asmidar dan Damaiwaty Ray. (2018). "Pengaruh Penggunaan Model Make A match Terhadap Kemampuan Mengenal Konsep Bilangan 1-10 Anak Usia 4-5 Tahun di TK IImi Insani”. Volume 4, No 2.

Peraturan Mentri Pendidikan dan Kebudayaan Republik Indonesia Nomor 137 Tahun 2014.

Saputri, Nofiyana Astifani. (2016). "Peningkatan Kemampuan Mengenal Lambang Bilangan Melalui Model Pembelajaran Kooperatif Tipe Mencari Pasangan Di Kelompok A Tk Nasional Samirono Depok Sleman". Edisi. 7 Tahun. 5.

Sugiono. 2010. Metode Penelitian Kuantitatif Kualitatif dan R\&D. Bandung. Alfabeta Bandung.

Sugiyono. 2015. Metodologi Penelitian Pendidikan. Bandung : Alfabeta.

Susanto, Ahmad. 2011. Perkembangan Anak Usia Dini. Jakarta : Kata Pena.

Yuliani, Dwi. 2017. Pengaruh Video Pembelajaran Terhadap Kemampuan Berhitung Permulaan Pada Anak Kelompok B di Taman Kanak-kanak Gugus VI Kecamatan Buleleng Tahun Pelajaran 2016/2017. Singaraja: Universitas Pendidikan Ganesha.

Undang-Undang Nomor 20 Tahun 2003. Sistem Pendidikan Nasional. 